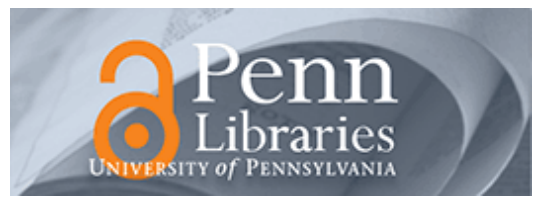

University of Pennsylvania

ScholarlyCommons

Management Papers

Wharton Faculty Research

2003

\title{
Learning about Failure: Bankruptcy, Firm Age, and the Resource- Based View
}

Stewart Thornhill

Raphael Amit

University of Pennsylvania

Follow this and additional works at: https://repository.upenn.edu/mgmt_papers

Part of the Business Administration, Management, and Operations Commons, Business Analytics Commons, Business and Corporate Communications Commons, Business Intelligence Commons, Management Information Systems Commons, Management Sciences and Quantitative Methods Commons, and the Organizational Behavior and Theory Commons

\section{Recommended Citation}

Thornhill, S., \& Amit, R. (2003). Learning about Failure: Bankruptcy, Firm Age, and the Resource-Based View. Organization Science, 14 (5), 497-509. http://dx.doi.org/10.1287/orsc.14.5.497.16761

This paper is posted at ScholarlyCommons. https://repository.upenn.edu/mgmt_papers/310

For more information, please contact repository@pobox.upenn.edu. 


\title{
Learning about Failure: Bankruptcy, Firm Age, and the Resource-Based View
}

\author{
Abstract \\ Systematic differences in the determinants of firm failure between firms that fail early in their life and \\ those that fail after having successfully negotiated the early liabilities of newness and adolescence are \\ identified. Analysis of data from 339 Canadian corporate bankruptcies suggests that failure among \\ younger firms may be attributable to deficiencies in managerial knowledge and financial management \\ abilities. Failure among older firms, on the other hand, may be attributable to an inability to adapt to \\ environmental change. \\ Keywords \\ liability of newness, resource-based view, bankruptcy \\ Disciplines \\ Business Administration, Management, and Operations | Business Analytics | Business and Corporate \\ Communications | Business Intelligence | Management Information Systems | Management Sciences and \\ Quantitative Methods | Organizational Behavior and Theory
}




\title{
Learning from failure: Organizational mortality and the resource-based view
}

\author{
by \\ Stewart Thornhill * \\ Corresponding author \\ and \\ Raphael Amit ** \\ 11F0019MIE No. 202 \\ ISSN: 1205-9153 \\ ISBN: 0-662-34152-X
}

Micro-Economic Analysis Division

18-H, R.H. Coats Building, Ottawa, K1A 0T6

Statistics Canada

How to obtain more information :

National inquiries line: 1800 263-1136

E-Mail inquiries: infostats@statcan.ca

The paper is available on Internet: (www.statcan.ca)

* Richard Ivey School of Business

The University of Western Ontario

London, Ontario

N6A 3K7

** Robert B. Goergen Professor of Entrepreneurship

Management Department, Room 2012 SH-DH

The Wharton School, University of Pennsylvania

3620 Locust Walk, Philadelphia PA 19104-6364

\section{August 2003}

This paper represents the views of the authors and does not necessarily reflect the opinions of Statistics Canada.

The authors are most grateful for the generous financial support of the Social Sciences and Humanities Research Council of Canada. We are also grateful to John Baldwin and the MicroEconomic Analysis Division of Statistics Canada. 


\section{Table of Contents}

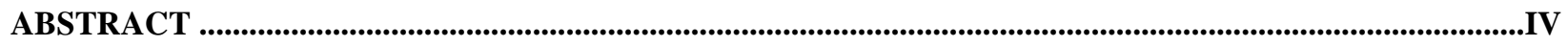

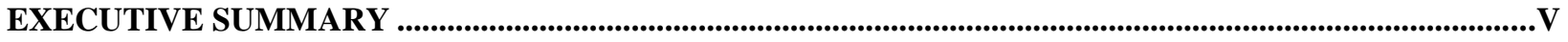

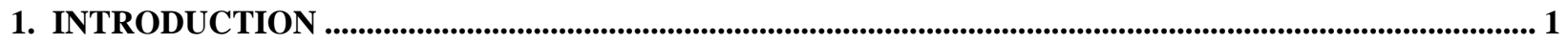

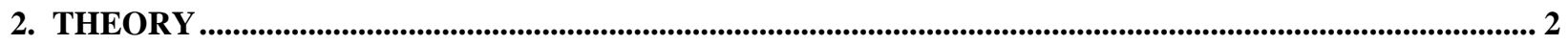

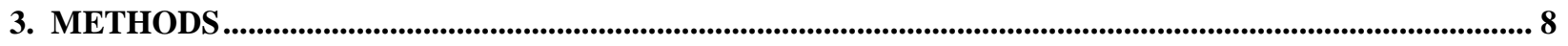

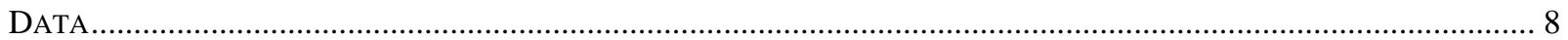

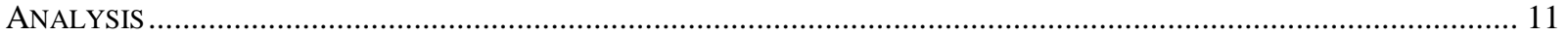

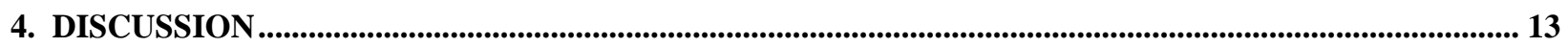

APPENDIX 1：DETAILS OF BANKRUPTCY SURVEY ITEMS ......................................................... 15

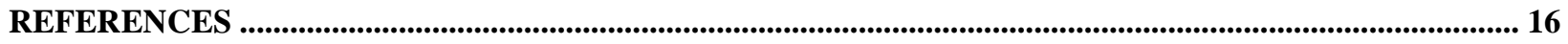




\section{Abstract}

This paper examines the factors underlying firm failure and contrasts the failure mechanisms for young firms from those of older organizations. We suggest that there are systematic differences between the determinants of firm failure for firms that fail early in life and those that fail after having successfully negotiated the early liabilities of newness and adolescence. Data from 339 Canadian corporate bankruptcies confirm that younger firms fail because of inadequacies in managerial knowledge, and financial management abilities. Older firms, on the other hand, are more likely to fail because of an inability to adapt to environmental change.

Keywords: failure, bankruptcy, firm age, resource-based

Published by authority of the Minister responsible for Statistics Canada

(C) Minister of Industry, 2003

All rights reserved. No part of this publication may be reproduced, stored in a retrieval system or transmitted in any form or by any means, electronic, mechanical, photocopying, recording or otherwise without prior written permission from Licence Services, Marketing Division, Statistics Canada, Ottawa, Ontario, Canada K1A 0T6. 


\section{Executive Summary}

One of the fundamental questions in strategic management and entrepreneurship research is why some firms fail and others do not. The vast majority of organizational research has concentrated on successful firms. Yet, despite evidence that a failure is a more likely fate than survival for new firms, failures remain an understudied population. Further, much of the research on discontinuance has been conducted at the macro-level, examining population dynamics and the patterns of entry and exit over time. In the present study, we seek to contribute to our understanding of one specific type of failure-bankruptcy-and the causes underlying such failures for firms of different ages.

A clear and consistent finding of prior research is that firms face the highest failure risk when they are young and small. But if there are factors other than the liabilities of newness and smallness that contribute to firm failure, what are they and how can their influence be mitigated? From the perspective of the resource-based view of the firm, firms will fail if they are unable to generate self-sustaining levels of organizational rents. For new firms, the critical challenge then is to establish valuable resources and capabilities before initial asset endowments are depleted. Among older firms, which have survived the liabilities of newness, it is imperative to ensure that resources and capabilities continue to provide value as the competitive landscape changes. Thus, we should observe different causal mechanisms between firms that fail early and those that fail at a later stage. Young failures should be attributable to inadequate resources and capabilities (relative to initial endowments). Older failures should be attributable to a mismatch between resources and capabilities and strategic industry factors.

We evaluate the general proposition that the causes of failure vary as a function of firm age with data from a sample of 339 Canadian bankruptcies. By examining instances of bankruptcy in some detail, we are able to extend our knowledge of mortality dynamics beyond the scope of age, size, and population density mechanisms. Specifically, we examine the relationship between firm age at failure and firm-level resources and capabilities, along with industry competitive conditions. We argue that while age is strongly correlated with probability of survival or failure, there is an underlying, resource-based process at work. Over time, firms succeed or fail as a function of their ability to create and sustain value through the deployment of strategic assets. Bankruptcy, a specific type of discontinuance, occurs when a firm can no longer meet its financial obligations; it has failed to generate sufficient rents to remain a going concern. We suggest that, after controlling for size and industry membership, bankruptcy among younger firms is attributable to different causes than bankruptcy among older firms. The data provide support for our contention that failure does occur for different reasons as a function of firm age. The findings are consistent with the expectations of the resource-based view, and complementary to population-level studies of mortality.

The existence of firm-specific failure determinants offers support to the resource-based theory of the firm, and contributes a more-fine-grained perspective to the study of organizational ecology. Our finding that a lack of managerial competencies is implicated in bankruptcy outcomes is consistent with the resource-based view's (RBV) perspective that firm performance is a function of intangible processes. The role of environmental change supports both the selection argument 
of organization ecology and the RBV emphasis on strategic assets and strategic industry factors. In other words, the environment, age, and size all matter, but there is more to the puzzle than these three components. This last implication should be of particular interest to managers. If the quality of management makes a difference for a population of failures, it surely matters for successful firms. 


\section{Introduction}

One of the fundamental questions in strategic management and entrepreneurship research is why some firms fail and others do not. The vast majority of organizational research has concentrated on successful firms. Yet, despite evidence that a failure is a more likely fate than survival for new firms, failures remain an understudied population (Baldwin et al., 1997; Bruderl, Preisendorfer and Ziegler, 1992). Further, much of the research on discontinuance has been conducted at the macro-level, examining population dynamics and the patterns of entry and exit over time. In the present study, we seek to contribute to our understanding of one specific type of failure_-bankruptcy_ and the causes underlying such failures for firms of different ages.

A clear and consistent finding of prior research is that firms face the highest failure risk when they are young and small (Carroll, 1983; Sorensen and Stuart, 2000). But if there are factors other than the liabilities of newness and smallness that contribute to firm failure (McGrath, 1999), what are they and how can their influence be mitigated? From the perspective of the resource-based view of the firm, firms will fail if they are unable to generate self-sustaining levels of organizational rents (Amit and Schoemaker, 1993). For new firms, the critical challenge then is to establish valuable resources and capabilities before initial asset endowments are depleted (Levinthal, 1991). Among older firms, which have survived the liabilities of newness, it is imperative to ensure that resources and capabilities continue to provide value as the competitive landscape changes. Thus, we should observe different causal mechanisms between firms that fail early and those that fail at a later stage. Young failures should be attributable to inadequate resources and capabilities (relative to initial endowments). Older failures should be attributable to a mismatch between resources and capabilities and strategic industry factors.

We evaluate the general proposition that the causes of failure vary as a function of firm age with unique data from a sample of Canadian bankruptcies. By examining instances of bankruptcy in some detail, we are able to extend our knowledge of mortality dynamics beyond the scope of age, size, and population density mechanisms. Specifically, we examine the relationship between firm age at failure and firm-level resources and capabilities, along with industry competitive conditions. The data provide support for our contention that failure does occur for different reasons as a function of firm age. The findings are consistent with the expectations of the resource-based view, and complementary to population-level studies of mortality. 


\section{Theory}

The resource-based view (RBV) of the firm depicts firms as heterogeneous bundles of idiosyncratic, hard-to-imitate resources and capabilities (e.g., Barney, 1991; Conner, 1991; Rumelt, 1984, 1991; Wernerfelt, 1984). Amit and Schoemaker (1993) posited that a firm's ability to capture economic rents is a function of how such capabilities are used to deploy and utilize a firm's resources. In their view, resources are "stocks of available factors that are owned or controlled by the firm" (1993: 35). Capabilities are "information-based, tangible or intangible processes that are firm-specific and are developed over time through complex interactions among the firm's resources" (1993, p. 35). Teece, Pisano and Shuen (1997) added a dynamic element to this view by arguing that "the competitive advantage of firms lies with its managerial and organizational processes, shaped by its (specific) asset position, and the path available to it." (1997, p. 518).

Amit and Schoemaker's (1993) model of Strategic Assets and Organizational Rents suggests that both the internally controlled resources and capabilities (R\&C) of a firm, and the externally determined strategic industry factors (SIF) determine whether a firm has strategic assets (SA) necessary to generate economic rents. Thus, organizational rents are more likely when $\mathrm{R} \& \mathrm{C}$ are aligned with SIF. Conversely, failure becomes more likely in the case of misalignment between what the firm can do and what the competitive environment requires.

New firms are able to observe the competitive environment before entry into a particular market. Except for very rare circumstances, new entrants must take competitive conditions as exogenous and craft their strategies accordingly. The creation of value-generating strategic assets thus depends on the ability to develop and manage appropriate $\mathrm{R} \& \mathrm{C}$. This challenge is amplified by resource constraints and the absence of established organizational routines.

The critical role of organizational routines was articulated by Stinchcombe (1965) in his seminal paper on the liability of newness. He identified four aspects of new organizations that make them more prone to failure than older, more established organizations: (a) new organizations must get by with general knowledge until members learn new, specific roles and functions, (b) during the role identification and formation process, there may be conflict, worry, and inefficiency, (c) relations with outside individuals and organizations must be forged, and an initial lack of trust may be a liability, and (d) new organizations lack stable ties with the customers they wish to serve.

In addition to the organizational liabilities noted by Stinchcombe, young firms may also lack knowledge about what they can do or should do (Jovanovic, 1982), or may not be sufficiently endowed with the requisite resources to execute their strategy (Lussier, 1995; Venkataraman, Van de Ven, Buckeye and Hudson, 1990). Fichman and Levinthal (1991) suggest that the liability of newness is not a monotonically decreasing function of firm age, but that there is an initial "honeymoon" period during which initial assets buffer the new organization. They argue that variations in the levels of initial assets affect the way time affects mortality rates. The time dependence occurs because the longer an organization survives (due to initial capital endowments), the more it will be able to develop relationship-specific capital and adapt to the environment. 
In another interpretation of the observed mortality patterns of young organizations, Levinthal (1991) developed a random-walk model comprised of the initial stock of organizational capital and the process governing the change in organizational capital over time. Based on the randomwalk model, he argued that there is no direct link between an organization's age and its reduced mortality risk. Older firms experience reduced mortality rates not because they are old but because their prior successes buffer them from current pressures. Organizational changes such as increased reliability and competence are thus not necessary to explain the declining mortality risk that accompanies age. Levinthal concluded that age might be a proxy for the broader construct of organizational capital.

The interaction between firm resources, industry factors, and probable survival outcomes is depicted graphically in Figure 1. In this diagram, the desired state is position $\mathrm{C}$ in which the external requirements are well-understood and firm $\mathrm{R} \& \mathrm{C}$ have value in the competitive context. New firms may begin in position B, from which the industry factors can be observed and understood, but the task of creating valuable competitive assets remains. Firms that can create and exploit valuable $\mathrm{R} \& \mathrm{C}$ before their initial assets are exhausted may escape the liability of newness and move to position $\mathrm{C}$.

\title{
Figure 1. Liabilities and Strategic Assets
}

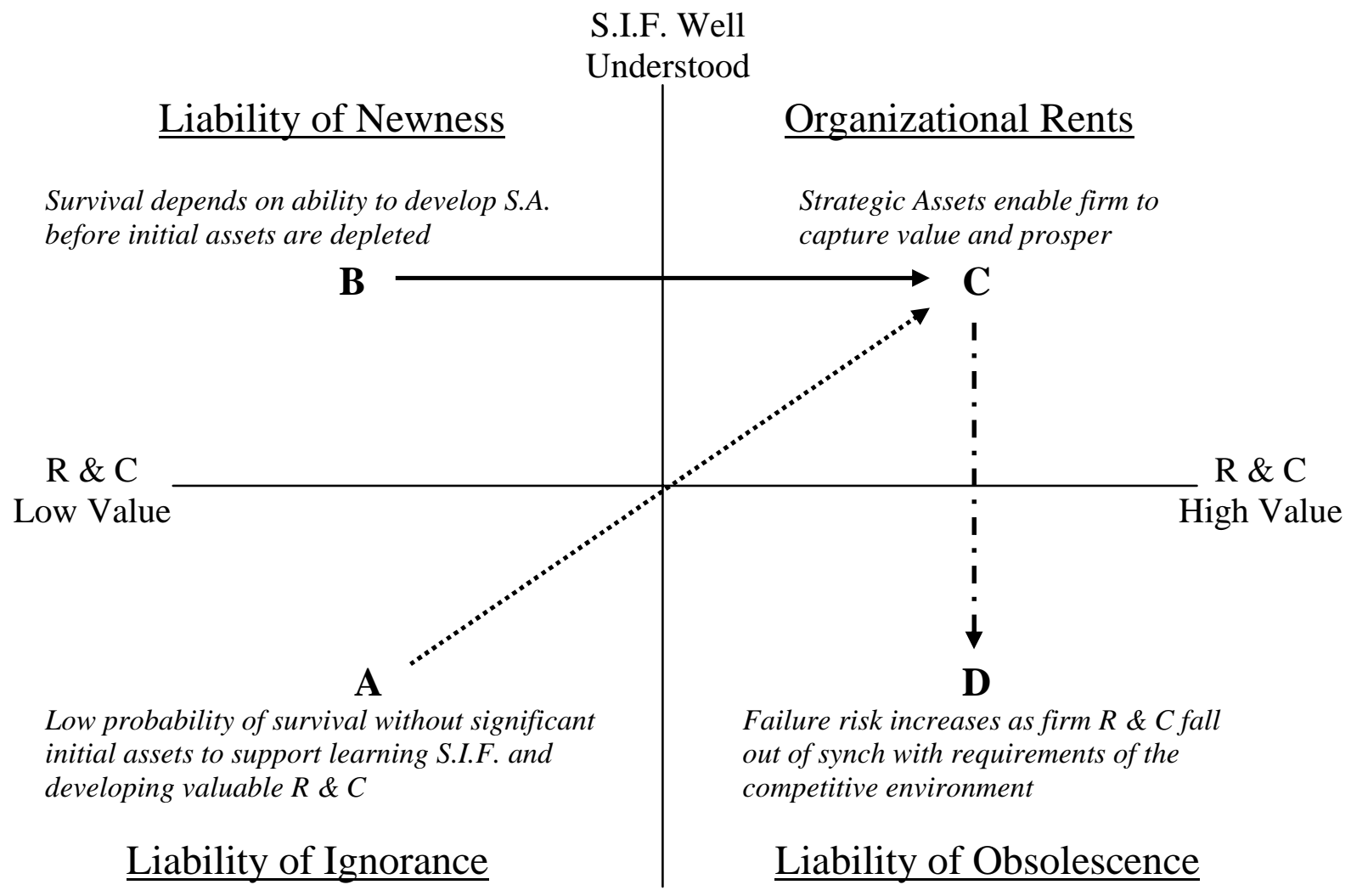

\author{
S.I.F. Poorly \\ Understood
}


Position A in Figure 1 also captures an aspect of the liability of newness. Firms in this position lack clear knowledge of industry requirements and the wherewithal to create and capture value. While moving from $\mathrm{A}$ to $\mathrm{C}$ is not impossible, it requires extraordinary learning and/or the presence of a significant initial endowment. Firms in both A and B share the burden of R\&C deficiencies, which must be overcome if they are to emerge from their hazardous period of newness.

Firms that survive through the early years face very different issues than do young enterprises. As noted by Aldrich and Auster (1986), "the major problem facing smaller and younger organizations is survival, whereas larger and older organizations face the problem of strategic transformation" (1986, p. 193). The established routines of older organizations, which in many cases were critical to their initial survival, can become liabilities in the face of changing competitive conditions (Hannan and Freeman, 1984). Organizational ecology asserts that the environment will select out unfit organizations, and that the ability to survive over time is a function of whether an organization is suited to both the current environment and the way in which the environment changes and evolves. Misalignment with the environment may expose firms to a liability of obsolescence (Barron, West and Hannan, 1994). Whether an organization ages well or badly thus depends on whether the effects of learning over time result in increased (positive) competence or increased (negative) rigidity (Sorensen and Stuart, 2000). In many instances, managers simply do not acknowledge that previously successful strategic postures have become uncompetitive (Harrigan, 1985, 1988).

Amburgey, Kelly, and Barnett (1993) noted that while older organizations may be severely affected by change, they are often well suited to withstand shocks by virtue of their accumulated asset stocks. Selection due to environmental change should affect those firms that have endured long enough to establish set routines and procedures, but that lack the ability to change as required by the evolution of their market or industry context. The tension between resource slack and efficiency is well known. In stable environments, the efficiency of older organizations should be an asset; however this can quickly become a liability in unstable or uncertain markets.

From the strategic assets framework, we suggest that firms will fail when the organizational rents become insufficient to support continuing operations. This will occur when $\mathrm{R} \& \mathrm{C}$ lose value relative to the demands of the environment. If firms fail because of an inability to adapt to changing competitive circumstances, this represents a significantly different process of failure than that articulated by the liability of newness. In Figure 1, this can be seen as the transition from position $\mathrm{C}$ to $\mathrm{D}$.

For any firm, failure will be the result of insufficient rent generation. For young firms, with a given initial endowment, having R\&C that are well matched to SIF will enhance the prospects of initial survival. For older firms, sustaining the connection between internal R\&C and external SIF is what matters. In sum, the theoretical tenets of the liabilities of newness and obsolescence are consistent with the strategic assets and organizational rents framework of the resource-based view. As presented in Figure 1, age is not the prime determinant of mortality, despite the strong correlative evidence that age is a strong predictor of failure. Instead, age is a proxy for internal organizational processes that evolve over time; the alignment or misalignment of firm capabilities with the competitive landscape. This leads to our first hypothesis. 


\section{H1: Failure of young firms will be attributable to different causes than failure of older firms.}

The nature of the causal differences is evident in Figure 1. Specifically, we propose that young organizations will suffer from resource and capability deficiencies. This is the essence of the liability of newness expressed in the language of the RBV. Older firms, having presumably developed valuable $\mathrm{R} \& \mathrm{C}$ in their evolution from being young to being older, will be prone to misalignment with strategic industry factors. Thus, a resource-based perspective can also be applied to the liability of obsolescence. The age-specific failure dynamics are stated more formally in the following hypotheses.

\section{H2: Failure of older firms will be attributable to changes in Strategic Industry Factors.}

\section{H3: Failure of young firms will be attributable to deficiencies in Resources and Capabilities}

The latter hypothesis regarding the role of $\mathrm{R} \& \mathrm{C}$ in the liability of newness is amenable to greater refinement. Resources and capabilities encompass a broad array of assets, tangible and intangible, as well as numerous ways of deploying such assets in the pursuit of economic rents. Levinthal (1991) observed that firms fail when poor performance erodes asset stocks. His definition of assets includes not only financial assets, but also market position, distribution systems, manufacturing infrastructure, and technological capabilities. Levinthal refers to this conglomeration of financial and non-financial assets as "organizational capital." D'Aveni (1989) describes organizations as accumulators of financial and managerial assets. The net asset base of a firm influences the risk of default to creditors. We can thus describe young firms as being prone to shortages of tangible assets (e.g., real capital) and/or intangible assets (e.g., human capital).

A review of prior research makes it clear that the fitness of a firm is damaged by managerial deficiencies in a number of areas (Gaskill, Van Auken and Manning, 1993; Larson and Clute, 1979; McKinlay, 1979). Younger firms may have greater difficulty generating revenues while concurrently dealing with a variety of start-up costs that older enterprises have long since absorbed. From our review of firm-level empirical studies (see Table 1), general management and financial planning and control were the most commonly cited contributors to firm mortality. The development of a sound product-market strategy is also identified in the literature. Consistent with our position that firm-specific $\mathrm{R} \& \mathrm{C}$, rather than age, are critical to survival or demise, we suggest that general, financial, and marketing management deficiencies will play a greater role in the failure of young firms than older businesses.

The crux of our argument is that the liability of newness has specific elements that originate with the management of a firm. For example, as firms age and managers gain greater breadth and depth of knowledge about customers, suppliers, competitors, etc., any knowledge deficiencies in these domains will become less of a liability. Young firms will thus be more prone to failure as a function of general management knowledge, skills, and abilities. 
Table 1. Empirical Studies of Organizational Mortality

\begin{tabular}{|c|c|c|c|c|c|c|c|c|c|c|c|}
\hline & \multicolumn{4}{|c|}{ Firm Attributes } & \multicolumn{3}{|c|}{ Owner/Manager Attributes } & \multicolumn{4}{|c|}{ Operational Characteristics } \\
\hline & Age & Size & $\begin{array}{l}\text { Industry/ } \\
\text { Environ. }\end{array}$ & $\begin{array}{c}\text { Initial } \\
\text { Capital }\end{array}$ & Age & Education & Experience & Performance & $\begin{array}{c}\text { Prod/Mkt } \\
\text { Strategy }\end{array}$ & $\begin{array}{c}\text { General } \\
\text { Mgmt }\end{array}$ & $\begin{array}{c}\text { Financial } \\
\text { Control }\end{array}$ \\
\hline POPULATION-LEVEL STUDIES & & & & & & & & & & & \\
\hline Amburgey et al. (1993) & $\mathrm{X}$ & & $\mathrm{X}$ & & & & & & & & \\
\hline Bates (1990) & $\mathrm{X}$ & $\mathrm{X}$ & & $\mathrm{X}$ & $\mathrm{X}$ & $\mathrm{X}$ & & & & & \\
\hline Bates and Nucci (1989) & $\mathrm{X}$ & $\mathrm{X}$ & & & & & & $\mathrm{X}$ & & & \\
\hline Bruderl and Schussler (1990) & $\mathrm{X}$ & $\mathrm{X}$ & & & & & & & & & \\
\hline Carroll (1983) & $\mathrm{X}$ & & $\mathrm{X}$ & & & & & & & & \\
\hline Carroll and Delacroix (1982) & $\mathrm{X}$ & & $\mathrm{X}$ & & & & & & & & \\
\hline Carroll and Huo (1986) & & & $\mathrm{X}$ & & & & & & & & \\
\hline Dunne et al. (1988) & $\mathrm{X}$ & $\mathrm{X}$ & $\mathrm{X}$ & & & & & & & & \\
\hline Freeman et al. (1983) & $\mathrm{X}$ & $\mathrm{X}$ & & & & & & & & & \\
\hline Levinthal (1991) & $\mathrm{X}$ & $\mathrm{X}$ & & $\mathrm{X}$ & & & & & & & \\
\hline Phillips and Kirchhoff (1989) & $\mathrm{X}$ & $\mathrm{X}$ & $\mathrm{X}$ & & & & & & & & \\
\hline Preisendorfer and Voss (1990) & $\mathrm{X}$ & & $\mathrm{X}$ & & $\mathrm{X}$ & & $\mathrm{X}$ & & & & \\
\hline Ranger-Moore (1997) & $\mathrm{X}$ & $\mathrm{X}$ & $\mathrm{X}$ & & & & & $\mathrm{X}$ & & & \\
\hline Stearns et al. (1995) & & & $\mathrm{X}$ & & & & & & $\mathrm{X}$ & & \\
\hline MULTI-LEVEL STUDIES & & & & & & & & & & & \\
\hline Fichman and Levinthal (1991) & $\mathrm{X}$ & $\mathrm{X}$ & & $\mathrm{X}$ & & & & & & & \\
\hline Gimeno et al. (1997) & $\mathrm{X}$ & $\mathrm{X}$ & & & & $\mathrm{X}$ & $\mathrm{X}$ & & & & \\
\hline Henderson (1999) & $\mathrm{X}$ & $\mathrm{X}$ & $\mathrm{X}$ & & & & & $\mathrm{X}$ & $\mathrm{X}$ & & \\
\hline Pennings et al. (1998) & $\mathrm{X}$ & & & & & $\mathrm{X}$ & $\mathrm{X}$ & & & & \\
\hline Singh et al. (1986) & $\mathrm{X}$ & & $\mathrm{X}$ & & & & & & & & \\
\hline Singh et al. (1986) & $\mathrm{X}$ & & $\mathrm{X}$ & & & & & & & & \\
\hline FIRM-LEVEL STUDIES & & & & & & & & & & & \\
\hline Baldwin et al. (1997) & & & & & & & & & & $\mathrm{X}$ & $\mathrm{X}$ \\
\hline Boardman et al. (1981) & $\mathrm{X}$ & $\mathrm{X}$ & $\mathrm{X}$ & & & & & $\mathrm{X}$ & & $\mathrm{X}$ & \\
\hline Bruderl et al. (1992) & & & & & & $\mathrm{X}$ & $\mathrm{X}$ & & & & \\
\hline Carter et al. (1997) & & & & $\mathrm{X}$ & & $\mathrm{X}$ & $\mathrm{X}$ & & $\mathrm{X}$ & & \\
\hline Cooper et al. (1994) & & & $\mathrm{X}$ & $\mathrm{X}$ & & $\mathrm{X}$ & $\mathrm{X}$ & & & & $\mathrm{X}$ \\
\hline Daily (1995) & & $\mathrm{X}$ & & & & & & & & & $\mathrm{X}$ \\
\hline D'Aveni (1989) & & & $\mathrm{X}$ & & & $\mathrm{X}$ & $\mathrm{X}$ & $\mathrm{X}$ & & & \\
\hline Fredland and Morris (1976) & $\mathrm{X}$ & $\mathrm{X}$ & $\mathrm{X}$ & & & & $\mathrm{X}$ & & & & \\
\hline Gaskill et al. (1993) & & & $\mathrm{X}$ & & $\mathrm{X}$ & $\mathrm{X}$ & & $\mathrm{X}$ & & $\mathrm{X}$ & $\mathrm{X}$ \\
\hline Hall (1992) & $\mathrm{X}$ & $\mathrm{X}$ & $\mathrm{X}$ & $\mathrm{X}$ & & & & & $\mathrm{X}$ & $\mathrm{X}$ & \\
\hline Hall (1994) & $\mathrm{X}$ & $\mathrm{X}$ & & & $\mathrm{X}$ & $\mathrm{X}$ & & & & & \\
\hline Hambrick and D'Aveni (1988) & $\mathrm{X}$ & $\mathrm{X}$ & $\mathrm{X}$ & & & & & & & $\mathrm{X}$ & \\
\hline Kalleberg and Leicht (1991) & $\mathrm{X}$ & & $\mathrm{X}$ & & & & $\mathrm{X}$ & & & & \\
\hline Keasey and Watson (1987) & $\mathrm{X}$ & & & & $X$ & & & $\mathrm{X}$ & & & \\
\hline Larson and Clute (1979) & & & & & & & & & & $\mathrm{X}$ & $\mathrm{X}$ \\
\hline Litvak and Maule (1980) & & & & & & & & & & $\mathrm{X}$ & $\mathrm{X}$ \\
\hline Lussier (1995) & & & & $\mathrm{X}$ & $\mathrm{X}$ & $\mathrm{X}$ & $\mathrm{X}$ & & & & $\mathrm{X}$ \\
\hline McKinlay (1979) & & & & & & & & $\mathrm{X}$ & & $\mathrm{X}$ & $\mathrm{X}$ \\
\hline Mitchell (1991) & & & & & & & & & & & \\
\hline Mitchell (1994) & & & $\mathrm{X}$ & & & & $\mathrm{X}$ & $\mathrm{X}$ & & & \\
\hline Mitchell et al. (1994) & & & & & & & & $\mathrm{X}$ & & & \\
\hline Moulton and Thomas (1993) & & $\mathrm{X}$ & & & & & & & $\mathrm{X}$ & & \\
\hline O'Neill and Duker (1986) & & & $\mathrm{X}$ & & & & & & & & \\
\hline Venkataraman et al. (1990) & $\mathrm{X}$ & $\mathrm{X}$ & & $\mathrm{X}$ & & & & & & & \\
\hline
\end{tabular}


General management skills have been implicated in several studies of firm mortality (e.g., Larson and Clute, 1979; Wichman, 1983, Gaskill, et al., 1993). Cooper, Gimeno-Gascon and Woo (1994) noted that "management know-how may affect the performance of the firm through more promising strategies or better management methods" (1994, p. 374). They further suggested that industry-specific know-how would benefit firms by "providing a tacit understanding of the key success factors in an industry, specialized knowledge of the product or technologies, or accumulated goodwill with customers and/or suppliers" (1994, p. 374-375).

\section{H3a: Failure of young firms will be attributable to deficiencies in general management skills.}

Boardman, Bartley and Ratliff (1981) examined the issue of financial management and firm failure. In addition to the oft-cited issue of insufficient capital at inception, they also noted that unsuccessful managers also mismanaged those resources that were available and/or failed to determine appropriate policies to finance subsequent growth of the business. Their empirical results also reveal that "failed companies exhibited an increasingly unfavourable position with respect to the size of long-term debt to total assets" (1981, p. 39). The management of capital and the maintenance of an appropriate capital structure are thus critical for firm survival.

\section{H3b: Failure of young firms will be attributable to deficiencies in financial management skills.}

Developing a customer base is critical to the survival of any business, regardless of industry or the nature of the product or service offering. Inefficient marketing was explicitly identified as a cause of failure in Hall's (1992) comprehensive study of business failure in the U.K. Mitchell (1994), in his study of the medical equipment product market, concluded that "From a combined economic and ecological perspective, a business ceases to be a candidate for dissolution as soon as it creates commercially successful routines" (1994, p. 599). Litvak and Maule (1980), in a longitudinal study of business failures, reported that "The most significant business problem area was that of marketing, of the lack of it" (1980, p. 76). Our final hypothesis focuses on this specific aspect of managerial competence.

\section{H3c: Failure of young firms will be attributable to deficiencies in market development skills.}

In summary, we argue that while age is strongly correlated with probability of survival or failure, there is an underlying, resource-based process at work. Over time, firms succeed or fail as a function of their ability to create and sustain value through the deployment of strategic assets. Bankruptcy, a specific type of discontinuance, occurs when a firm can no longer meet its financial obligations; it has failed to generate sufficient rents to remain a going concern. In the next section, we evaluate our hypotheses with data from 339 bankruptcies. 


\section{Methods}

Our empirical analysis includes only bankrupt firms. This restricted set of business exits excludes other types of firm exits (i.e., discontinuances) that are typically captured in organizational ecology studies. However, it does capture failure in the extreme, and ensures that we do not confound orderly discontinuance or exit due to high performance thresholds with true failure. Firms that are insolvent to the point of legal proceedings have clearly failed to meet the market's threshold of fulfilling their financial obligations. Cochrane (1981) depicted failure as a series of nested conditions. The most general definition is discontinuance. Then, in increasing order of specificity and decreasing order of subset size are; (1) failures as opportunity costs; (2) termination with losses or to avoid losses, and; (3) bankruptcy. Performance thresholds are also important to consider in the context of business failures. Gimeno, Folta, Cooper and Woo (1997) established that a significant factor in the continuance-discontinuance decision for many entrepreneurs is their own acceptable threshold of performance. Firms that appear to be underperformers may persist if their thresholds are sufficiently low while other, relatively superior performers may exit if their thresholds are sufficiently high.

The data set, described below, is comprised entirely of firms that have exited by way of bankruptcy. We are therefore unable to investigate the issues of survival versus failure; for this, it would be necessary to have matching information on both failures and survivors. There is, however, much that can be learned from a post-mortem analysis of failures. The research question and the answers we glean are different from the more usual queries into survival and discontinuance. We propose that the determinants of failure vary as a function of firm age at failure. To understand whether this is so, we feel that it is appropriate to examine a sample of unsuccessful companies. Research into determinants of firm success routinely examines relative success within samples of surviving enterprises. The fact that failures are not included in such samples does not preclude the studies from contributing to our understanding of managerial processes. In a similar vein, the present analysis is focused solely on an understudied segment of the economy that has demonstrated its lack of viability. The ability to dig down into the causes of failure by studying specific instances, rather than macro-economic indicators, is a unique strength of our data.

\section{Data}

The data used in this study is based on a survey of bankruptcy trustees who completed a questionnaire while they were handling active bankruptcy files. The real-time method of data collection mitigates problems of retrospective recall bias. The survey was developed with the Canadian Insolvency Practitioners Association and compiled by Statistics Canada (Baldwin et al., 1997). All corporate bankruptcies in Canada are processed through the office of the Superintendent of Bankruptcies, which assigns a trustee to each case. Chartered Insolvency Practitioners are individuals (typically, Chartered Accountants) who have completed three years of prescribed study under the National Insolvency Qualification Program and successfully completed the National Insolvency Examination. As independent, third-parties, the trustees can provide objective reporting of the circumstances of each bankruptcy. They thus bring valuable objectivity and experience in evaluating the causes of failure. 
Table 2. Correlation Matrix and Summary Statistics

\begin{tabular}{|c|c|c|c|c|c|c|c|c|c|c|c|c|c|}
\hline & 1 & 2 & 3 & 4 & 5 & 6 & 7 & 8 & 9 & 10 & 11 & 12 & 13 \\
\hline 1 Firm Age & 1.00 & & & & & & & & & & & & \\
\hline 2 Assets $(\$ M)$ & $0.19 *$ & 1.00 & & & & & & & & & & & \\
\hline 3 Technological Change & $0.12 *$ & -0.02 & 1.00 & & & & & & & & & & \\
\hline 4 Market Change & $0.15^{*}$ & 0.06 & $0.62 *$ & 1.00 & & & & & & & & & \\
\hline 5 Legal Change & 0.08 & 0.01 & $0.32 *$ & $0.29 *$ & 1.00 & & & & & & & & \\
\hline 6 Capital Structure & -0.01 & $0.13 *$ & $0.28 *$ & $0.23 *$ & $0.14^{*}$ & 1.00 & & & & & & & \\
\hline 7 Undercapitalization & $-0.12 *$ & -0.02 & $0.16^{*}$ & $0.13 *$ & $0.12 *$ & $0.52 *$ & 1.00 & & & & & & \\
\hline 8 Breadth of Knowledge & $-0.12 *$ & $0.13 *$ & 0.09 & 0.02 & $0.12 *$ & $0.30 *$ & $0.28 *$ & 1.00 & & & & & \\
\hline 9 Depth of Knowledge & -0.06 & $0.12 *$ & 0.09 & 0.05 & 0.10 & $0.29 *$ & $0.29 *$ & $0.80 *$ & 1.00 & & & & \\
\hline 10 Operational Control & -0.04 & $0.13 *$ & $0.19 *$ & $0.12 *$ & $0.13^{*}$ & $0.19 *$ & $0.19 *$ & $0.49 *$ & $0.52 *$ & 1.00 & & & \\
\hline 11 Pricing & -0.09 & 0.05 & $0.17 *$ & $0.20 *$ & $0.22 *$ & $0.27 *$ & $0.21 *$ & $0.30 *$ & $0.31 *$ & $0.20 *$ & 1.00 & & \\
\hline 12 Product Quality & 0.06 & -0.03 & $0.41 *$ & $0.39 *$ & $0.19 *$ & $0.18^{*}$ & $0.18^{*}$ & 0.08 & $0.11 *$ & $0.18 *$ & $0.24 *$ & 1.00 & \\
\hline 13 Niche Marketing & 0.06 & -0.01 & $0.31 *$ & $0.29 *$ & $0.22 *$ & $0.13^{*}$ & 0.08 & $0.11^{*}$ & $0.18 *$ & $0.17 *$ & $0.33 *$ & $0.43 *$ & 1.00 \\
\hline Mean & 7.81 & 0.28 & 0.99 & 1.44 & 0.89 & 2.82 & 3.04 & 2.62 & 2.58 & 2.28 & 2.00 & 1.32 & 1.27 \\
\hline Std. Dev. & 7.83 & 0.67 & 1.06 & 1.37 & 0.93 & 1.79 & 1.70 & 1.47 & 1.48 & 1.57 & 1.46 & 1.22 & 1.16 \\
\hline
\end{tabular}

Correlation coefficients $>0.105$ are significant at $\mathrm{p}<0.05$. 
There were a total of 1,910 bankruptcies in Canada in the six-month period from March to August 1996. ${ }^{1}$ Surveys were sent to a random sample of trustees for 1085 of these cases and 550 responses were obtained (51\%). A total of 339 of these surveys contained complete responses to the items of interest to this research study, including the age of the business at the time of bankruptcy. Means, standard deviations, and inter-item correlation coefficients are presented in Table 2.

The dependent variable in our models is firm age at time of bankruptcy. Due to the highly skewed nature of the age distribution in our sample, we log-normalized age to better approximate a normal distribution. Twenty-nine percent of the firms in the sample were one or two years old at the time of bankruptcy, $40 \%$ were in the three- to-nine-year-old range, and the remaining $30 \%$ were ten years old or more. The mean age of the firms in our sample was 7.8 years (median 5.0).

We use a total of four predictor variables to test our hypotheses. Our measure of industry competitive conditions is derived from survey items in which the bankruptcy trustees were asked to report on the extent to which the firm was affected by: (a) changes in market conditions, (b) changes in technology, and (c) legislative changes. Respondents used a 5-point Likert-type scale to indicate the extent to which a given factor contributed to the bankruptcy. Principal components analysis indicated that these items loaded strongly on a single factor with an Eigenvalue of 1.84. (See Appendix for details of survey questions, factor loadings and alpha coefficients). The derived factor variable serves as our proxy for the level of industry turbulence and change. This measure was used to evaluated our hypothesis on the liability of obsolescence $(\mathrm{H} 2)$.

We also used the principal components technique to create three other composite factor variables, each of which were used to evaluate our specific hypotheses on the liability of newness (H3). A general management factor was derived to test Hypothesis 3a based on the manager's (a) breadth of knowledge, (b) depth of knowledge, (c) and control. Breadth was defined as the level of knowledge across functional areas (e.g., marketing, finance, operations), while depth was the extent of knowledge within the functions. The derived factor variable serves as a proxy for general managerial abilities.

A two-item factor was used to test for the impact of financial management resources and capabilities within the failed organizations. The relative contribution of unbalanced capital structure and poor capitalization are captured in our variable for $\mathrm{H} 3 \mathrm{~b}$. Our final variable for market development ( $\mathrm{H} 3 \mathrm{c}$ ) evaluated the impact of (a) pricing strategy, (b) product quality, and (c) the establishment of market position. By decomposing the firm's $\mathrm{R} \& \mathrm{C}$ into specific areas of general management, financial management, and market development, we are able to gain more detailed estimates about the causes of failure than would be possible through the use of more general proxies for organizational capital.

\footnotetext{
${ }^{1}$ During the time of data collection, there were no extraordinary shocks or other triggering events that made this a noteworthy period of Canadian economic history. The Canadian economy typically shadows the dominant U.S. economy and, while different, should be representative of business processes in most OECD nations. The data collection period of six months was determined by dual considerations of desirable sample size and costs of data acquisition.
} 
In addition to the independent variables described above, we also included control variables for industry membership and firm size in our regressions. Indicator variables were used for the following industry categories: (1) wholesale and retail $\left(\mathrm{n}_{1}=132\right),(2)$ food, accommodation and beverages $\left(n_{2}=43\right)$, (3) other services $\left(n_{3}=93\right)$, and (4) primary and manufacturing industries $\left(\mathrm{n}_{4}=71\right){ }^{2}$ Seventy-eight percent of the bankrupt firms were in service industries, a proportion that is representative of the general composition of the Canadian economy (Baldwin et al., 1997; Thornhill and Amit, 1998, 2000).

We also include a measure of firm size: assets at time of failure. The inclusion of this variable is more problematic in the study of bankruptcies than in studies of successful firms, for which the use of asset levels to define size is relatively unambiguous. In the case of defunct enterprises, it is highly probable that asset depletion has occurred along the road to ruin (Hambrick and D'Aveni, 1988). However, there is also a well-established relationship between size and likelihood of failure: the liability of smallness (c.f. Delacroix and Swaminathan, 1991; Baum and Oliver, 1991). Inclusion of firm asset level as a control variable is intended to capture variance associated with this known effect and thus improve our ability to evaluate the influence of the hypothesized age-specific relationships. ${ }^{3}$

\section{Analysis}

We utilized ordinary least squares (OLS) regression models to evaluate the effects of our control and predictor variables. The results of the regression analyses are presented in Table 3 . Two models are reported. The first includes our control variables plus the measure for industry change (H2). The second model includes all variables from Model 1 plus the three factor variables specified in Hypothesis $3 .^{4}$

The measure for firm size was positively and significantly associated with age at failure, confirming the expected age-size relationship. Two of the industry dummy variables were also significant. The positive sign of the coefficient for retail and wholesale indicates that failures in this industry segment were typically older firms, while the opposite effect was evident among firms in the food, accommodation and beverage sector.

All three of the managerial variables had negative coefficients in the regression models, indicating greater influence among younger bankruptcies, although there was strong significance $(\mathrm{p}<0.05)$ for only general management $(\mathrm{H} 3 \mathrm{a})$ and weaker significance $(\mathrm{p}<0.10)$ for the financial management variable $(\mathrm{H} 3 \mathrm{~b})$. Market development was not significant in the analysis.

\footnotetext{
${ }^{2}$ The requisite omitted industry (4) primary and manufacturing industries in our models. When this industry is specified and another industry omitted as the base case (e.g., other services), it is not a significant predictor of age at failure.

${ }^{3}$ When the asset variable is excluded from the regressions, the results are qualitatively the same.

${ }^{4}$ In order to evaluate whether the inclusion of the management variables represented a significant improvement over Model 1, we calculated an F-statistic to compare the nested models (Hamilton, 1992).

$$
\mathrm{F}_{\mathrm{n}-\mathrm{K}}^{\mathrm{H}}=\frac{(\mathrm{RSS}\{\mathrm{K}-\mathrm{H}\}-\mathrm{RSS}\{\mathrm{K}\}) / \mathrm{df}_{1-}}{\left[\operatorname{RSS}\{\mathrm{K}\} / \mathrm{df}_{2}\right]}
$$

The resulting $\mathrm{F}_{330}^{3}=4.14$, which is significant at $\mathrm{p}<0.01$. Thus, Model 2 is a significant improvement over Model 1 in explanatory power.
} 
Table 3. Regression Results

\begin{tabular}{l|l|l}
\hline \multicolumn{1}{c|}{$\mathrm{n}=339$} & \multicolumn{1}{|c}{$\begin{array}{c}\text { Model 1 } \\
\text { Controls and Industry }\end{array}$} & \multicolumn{1}{c}{ Model 2 } \\
& \multicolumn{1}{c}{ All Variables } \\
\hline Control Variables & $0.246^{* *}$ & \\
Firms Assets $(\$ M)$ & $0.281^{*}$ & $0.287^{* * *}$ \\
Retail \& Wholesale & $-0.399^{*}$ & $0.255^{\dagger}$ \\
Food, Accommodation. \& Beverage & -0.014 & $-0.416^{*}$ \\
Other Services & & -0.090 \\
\hline Predictor Variables & $0.088^{*}$ & \\
H2: Industry Change & & $0.126^{* *}$ \\
H3a: General Management & & $-0.086^{*}$ \\
H3b: Financial Management & & $-0.075^{\dagger}$ \\
H3c: Market Development & $1.466^{* * *}$ & -0.019 \\
\hline Intercept & $7.71^{* * *}$ & $1.488^{* * *}$ \\
F & 0.090 & $6.50^{* * *}$ \\
Adjusted $\mathrm{R}^{2}$ & 303.7 & 0.115 \\
RSS & 292.7 \\
\hline
\end{tabular}

Significance Levels (P-values): $\mathbf{t}<0.10 ; *<0.05 ; * *<0.01 ; * * *<0.001$

Note: As an alternative test, we also ran regressions on the individual survey items and performed clustered f-tests of statistical significance. The results are qualitatively the same: (H3a) General Management: $f(3,331)=4.07 ; p<0.08$, (H3b) Financial Management: $f(2,332)=3.44 ; p<0.03$, (H3c) Market Development: $f(3,331)=1.82 ; p<0.14$.

We may conclude from our regression results that there are, in fact, differences in the attributed causes of bankruptcy that vary as a function of age at failure. This supports Hypothesis 1 . The positive, significant coefficient for industry change also provides support for the RBV interpretation of the liability of obsolescence as articulated in Hypothesis 2. Among the subhypothesis offered as explanation for the liability of newness, there were varying degrees of support, permitting us only to conclude that Hypothesis 3 was partially supported by the data.

A closer examination of the individual item mean scores (Table 2) reveals that, independent of size, age, or industry context, undercapitalization was the issue given the greatest importance by the bankruptcy trustees. Next, in decreasing order of importance (i.e., mean score) were capital structure problems, breadth of knowledge, depth of knowledge, financial planning and control, and product pricing strategy. These results are consistent with the studies cited in Table 1.

Thus, while confirming that deficiencies in general management and financial management are common culprits in firm insolvency, the fresh findings to emerge from this research are the relationships between age at failure and the nature of the contributing causes. Younger firms are more likely to fail in food, accommodation and beverage industries, and due to problems with general management and financial management. Older failures on the other hand, are more likely to originate in wholesale or retail and to be subject to a turbulent competitive environment. These issues are discussed in greater detail below. 


\section{Discussion}

In her recent paper on entrepreneurial failure and real options reasoning, McGrath (1999) noted that there are benefits to be gained from the study of failures. She stated "By carefully analyzing failures instead of focusing only on successes, scholars can begin to make systematic progress on better analytical models of entrepreneurial value creation" $(1999$, p. 28). In a similar vein, Sitkin (1992) suggested, "failure is an essential prerequisite for learning" (1992, p. 232). Studies of failure can contribute to the eventual success of those who learn from their own mistakes as well as those who can learn vicariously from the experiences of others.

This paper represents an attempt to extend our understanding of the age-dependent mechanisms underlying firm failure. We began with the general proposition that there are different mechanisms at work when firms of differing ages become bankrupt. This perspective is an extension of the Amit and Schoemaker model of strategic assets and organizational rents. We suggest, as outlined in Figure 1, that younger firms expire if their initial asset endowments are exhausted before they are able to develop value-creating strategic assets. Such a situation will occur when resources and capabilities are not mobilized effectively and in step with the requirements of strategic industry success factors. Older firms, on the other hand, while having demonstrated the ability to survive the liabilities of newness, may find themselves in a noncompetitive position if they allow their resources and capabilities to lose relevance in a changing competitive environment. In this view, it is not youth or age that contribute to failure. Rather, age may be a proxy for underlying operational differences among firms that have been in existence for different periods of time. We hypothesized that, after controlling for size and industry membership, bankruptcy among younger firms would be attributable to different causes than bankruptcy among older firms. We tested our hypotheses using unique survey data from Canadian bankruptcy trustees and found varying degrees of support for the specified relationships. From this research, we can draw a number of conclusions and observations.

First, our findings lend empirical support to the resource-based view of the firm. While much empirical work has sought to establish a link between firm resources and capabilities and success, the flip side of the coin implies that an absence of strategic assets should lead down the road to insolvency. Whether firms are young, and trying to establish a viable competitive position, or older and trying to maintain or grow as the environment changes, the match between $\mathrm{R} \& \mathrm{C}$ and critical industry factors is paramount. As originally stated by Amit \& Schoemaker, "In sum, as the firm's environment changes, different sets of Strategic Assets may have to be developed by firms. Core Capabilities, by definition, cannot be purchased off the shelf, but require strategic vision, development time, and sustained investment. Decisions about Strategic Assets ... are among the most complex that managers encounter" (1993, p. 42; italics in original).

Second, this research contributes to a finer-grained understanding of the mechanisms underlying the well-known liability of newness. From Stinchcombe's (1965) original statement of the concept through a wealth of population ecology refinement, there are few relationships in social science as well established as the negative correlation between age and the likelihood of failure. The value added by the present line of research comes from the articulation of the different, agedependent causal factors of one specific type of failure: bankruptcy. Young firms may have 
knowledge of the industry, but suffer from a lack of valuable resources and capabilities. Older firms may have established resources and capabilities, but their value will diminish if not maintained relative to the demands of the competitive environment.

Third, the results confirm that industry membership is relevant to firm survival. Failure at an early age was associated with membership in the food, beverage and accommodation sector. Businesses such as pubs and restaurants are notorious for being short-lived, and it has been suggested that these "unglamorous" businesses may be prone to different strategy/performance dynamics than are firms in manufacturing or high-tech sectors of the economy (Brush and Chaganti, 1999). In contrast, firms in wholesale and retail were more likely to be amongst the older cohort of bankruptcies. This may be a consequence of recent changes to industry practices. The emergence of Internet vendors and "big-box" outlet stores may be eroding the competitive position of established, traditional wholesale and retail businesses. This evidence, coupled with the positive relationship between age and environmental change is consistent with a liability of obsolescence among firms in rapidly evolving industries (Barron et al., 1994).

Finally, this study adds credence to the view that there is value to be gained from the study of failed organizations. Just as medical science would be unlikely to progress by studying only healthy individuals, organization science may be limited in the knowledge attainable from the study of successful firms.

While these results shed new light on why firms fail at different ages, the data are not without limitations. Perhaps most obvious is the fact that the sample is drawn from a population of bankrupt enterprises. Clearly, the inclusion of surviving firms with comparable demographic characteristics would allow us to generalize the findings and have greater confidence in the empirical analysis. However, post-mortem analysis is not without precedent, nor is it without value, and the differences that have emerged between the younger and older failed firms represent a meaningful contribution to our understanding of firm mortality.

Two future lines of study suggested by this inquiry include (1) broadening the scope of exits under study to include modes of discontinuance other than bankruptcy and (2) contrasting young and old failures with a comparable population of young and old survivors. In each case, efforts should be made to reconcile observed population level dynamics with characteristics and behaviors that reflect the way firms do business.

The existence of firm-specific failure determinants offers support to the resource-based theory of the firm, and contributes a more-fine-grained perspective to the study of organizational ecology. Our finding that a lack of managerial competencies is implicated in bankruptcy outcomes is consistent with the RBV's perspective that firm performance is a function of intangible processes. The role of environmental change supports both the selection argument of organization ecology and the RBV emphasis on strategic assets and strategic industry factors. In other words, the environment, age, and size all matter, but there is more to the puzzle than these three components. This last implication should be of particular interest to managers. If the quality of management makes a difference for a population of failures, it surely matters for successful firms. 


\section{Appendix 1: Details of Bankruptcy Survey Items}

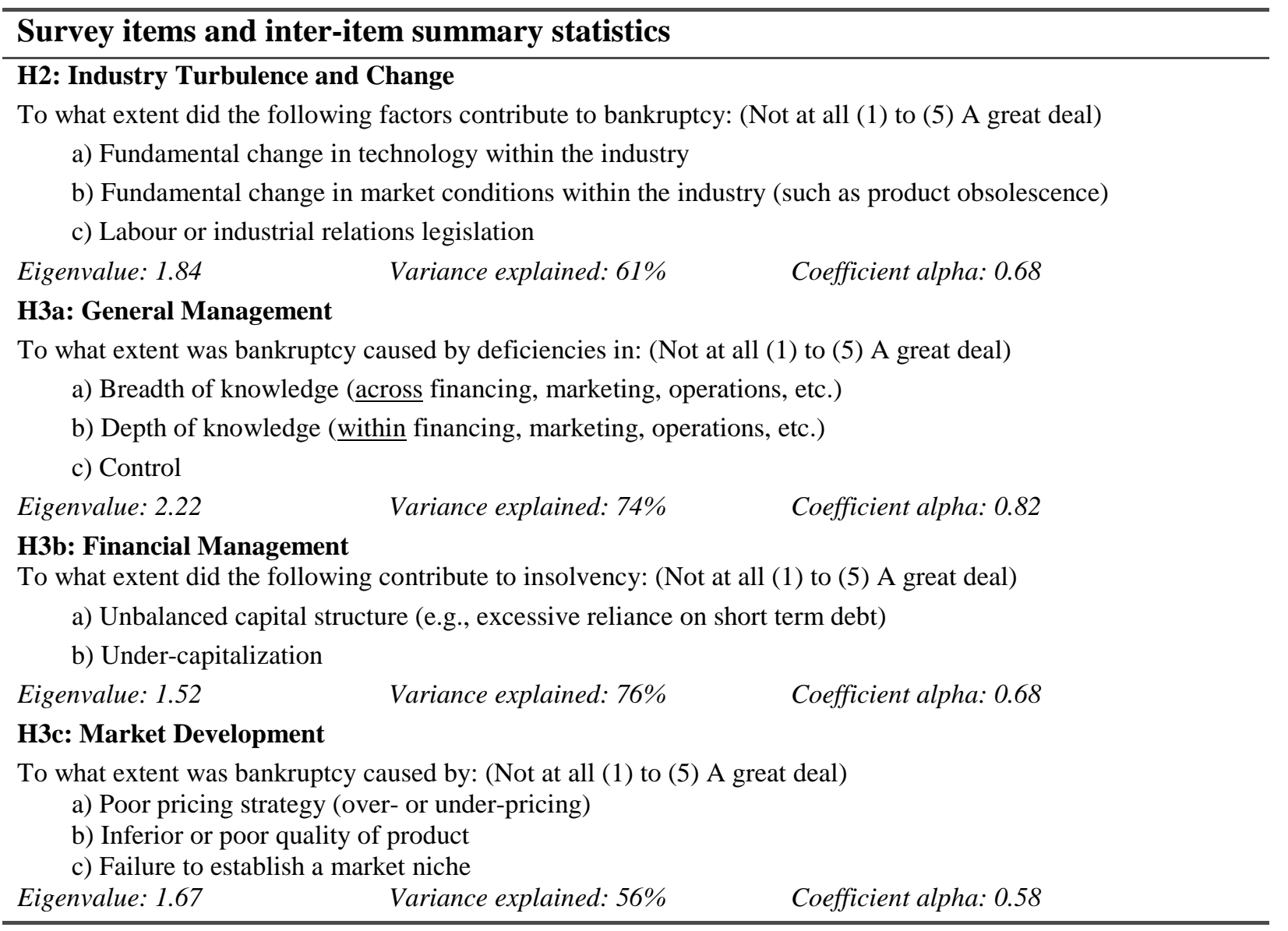




\section{References}

Aldrich, H.E. and E.R. Auster. 1986. "Even dwarfs started small: Liabilities of age and size and their strategic implications." Research in Organizational Behavior, 8(1): 165-198.

Amburgey, T.L, D. Kelly and W.P. Barnett. 1993. "Resetting the clock: The dynamics of organizational change." Administrative Science Quarterly, 38: 51-73.

Amit, R. and P.J.H. Schoemaker. 1993. "Strategic assets and organizational rent." Strategic Management Journal, 14: 33-46.

Baldwin, J.R., T. Gray, J. Johnson, J. Proctor, M. Rafiquzzaman and D. Sabourin. 1997. Failing Concerns: Business Bankruptcy in Canada. Catalogue no. 61-525. Analytical Studies Branch. Ottawa: Statistics Canada.

Barney, J.B. 1991. "Firm resources and sustained competitive advantage." Journal of Management, 17(1): 99-120.

Barron, D.N., E. West and M.T. Hannan. 1994. "A time to grow and a time to die: Growth and mortality of credit unions in New York City: 1914-1990." American Journal of Sociology, 100: $381-421$.

Bates, T. 1990. "Entrepreneur human capital inputs and small business longevity." Review of Economics \& Statistics, 72: 551-559.

Bates, T. and A. Nucci. 1989. "An analysis of small business size and rate of discontinuance." Journal of Small Business Management, 27(4): 1-7.

Baum, J.A.C. and C. Oliver. 1991. "Institutional linkages and organizational mortality." Administrative Science Quarterly, 36: 187-218.

Boardman, C.M., J.W. Bartley and R.B. Ratliff. 1981. "Small business growth characteristics." American Journal of Small Business, 5(Winter): 33-42.

Bruderl, J., P. Preisendorfer and R. Ziegler. 1992. "Survival chances of newly founded business organizations." American Sociological Review, 57: 227-242.

Bruderl, J. and R. Schussler. 1990. "Organizational mortality: The liability of newness and adolescence." Administrative Science Quarterly, 35: 530-547.

Brush, C.G. and R. Chaganti. 1999. "Businesses without glamour? An analysis of resources on performance by size and age in small service and retail firms." Journal of Business Venturing, 14: $233-257$.

Carroll, G.R. 1983. "A stochastic model of organizational mortality: Review and reanalysis." Social Science Research, 12: 303-329. 
Carroll, G.R. and J. Delacroix. 1982. "Organizational mortality in the newspaper industries of Argentina and Ireland: An ecological approach.” Administrative Science Quarterly, 27: 169-198.

Carroll, G.R. and Y.P. Huo. 1986. "Organizational task and institutional environments in evolutionary perspective: Findings from the local newspaper industry." American Journal of Sociology, 91: 838-873.

Carter, N.M., M. Williams and P.D. Reynolds. 1997. "Discontinuance among new firms in retail: The influence of initial resources, strategy, and gender." Journal of Business Venturing, 12: 125145.

Cochrane, A.B. 1981. "Small business mortality rates: A review of the literature." Journal of Small Business Management, 19(4): 50-59.

Conner, K.R. 1991. "A historical comparison of resource-based theory and five schools of thought within industrial organization economics: Do we have a new theory of the firm?" Journal of Management, 17: 121-154.

Cooper, A.C., F.J. Gimeno-Gascon and C.Y. Woo. 1994. "Initial human and financial capital as predictors of new venture performance." Journal of Business Venturing, 9: 371-395.

Daily, C.M. 1995. "The relationship between board composition and leadership structure and bankruptcy reorganization outcomes.” Journal of Management, 21: 1041-1056.

D'Aveni, R.A. 1989. "Dependability and organizational bankruptcy: An application of agency and prospect theory." Management Science, 35(9): 1120-1138.

Delacroix, J. and A. Swaminathan. 1991. "Cosmetic, speculative, and adaptive organizational change in the wine industry: A longitudinal study." Administrative Science Quarterly, 36: 631636.

Dunne, T., M.J. Roberts and L. Samuelson. 1988. "Patterns of firm entry and exit in US manufacturing industries." Rand Journal of Economics, 19(4): 495-515.

Fichman, M. and D.A. Levinthal. 1991. "Honeymoons and the liability of adolescence: A new perspective on duration dependence in social and organizational relationships." Academy of Management Review, 16: 442-468.

Fredland, J.E. and C.E. Morris. 1976. "A cross-sectional analysis of small business failure." American Journal of Small Business, 1(1): 7-18.

Freeman, J., G.R. Carrol and M.T. Hannan. 1983. "The liability of newness: Age dependence in organization death rates." American Sociological Review, 48: 692-710. 
Gaskill, L.R., H.E. Van Auken and R.A. Manning. 1993. "A factor analytic study of the perceived causes of small business failure." Journal of Small Business Management, 31(4): 1831.

Gimeno, J., T.B. Folta, A.C. Cooper and C.Y. Woo. 1997. "Survival of the fittest? Entrepreneurial human capital and the persistence of underperforming firms." Administrative Science Quarterly, 42: 750-783.

Hall, G. 1992. "Reasons for insolvency amongst small firms - A review and fresh evidence." Small Business Economics, 4: 237-250.

Hall, G. 1994. "Factors distinguishing survivors from failures amongst small firms in the UK construction sector.” Journal of Management Studies, 31: 737-760.

Hambrick, D.C. and R.A. D'Aveni. 1988. "Large corporate failures as downward spirals." Administrative Science Quarterly, 33: 1-23.

Hamilton, L.C. 1992. Regression with Graphics. Belmont. CA: Duxbury Press.

Hannan, M.T. and I. Freeman. 1984. "Structural inertia and organizational change." American Sociological Review, 49: 149-164.

Harrigan, K.R. 1985. Strategic Flexibility. Lexington, MA: D.C. Heath and Co.

Harrigan, K.R. 1988. Managing Maturing Businesses. Lexington, MA: D.C. Heath and Co.

Henderson, A.D. 1999. "Firm strategy and age dependence: A contingent view of the liabilities of newness, adolescence, and obsolescence." Administrative Science Quarterly, 44: 281-314.

Jovanovic, B. 1982. "Selection and the evolution of industry." Econometrica, 50(4), 649-670.

Kalleberg, A.L. and K.T. Liecht. 1991. "Gender and organizational performance: Determinants of small business survival and success.” Academy of Management Journal, 34: 136-161.

Keasey, K. and R. Watson. 1987. "Non-financial symptoms and prediction of small company failure: A test of Argenti's hypothesis." Journal of Business Finance and Accounting, 14: 335354.

Larson, C.M. and R.C. Clute. 1979. "The failure syndrome." American Journal of Small Business, 4(2): 35-43.

Levinthal, D.A. 1991. "Random walks and organizational mortality." Administrative Science Quarterly, 36: 397-420.

Litvak, I.A. and C.J. Maule. 1980. "Entrepreneurial success or failure - Ten years later." Business Quarterly: 68-78. 
Lussier, R.N. 1995. "A nonfinancial business success versus failure prediction model for young firms.” Journal of Small Business Management, 33(1): 8-20.

McGrath, R.G. 1999. "Falling forward: Real options reasoning and entrepreneurial failure." Academy of Management Review, 24(1): 13-30.

McKinlay, R.A. 1979. "Some reasons for business failures in Canada." Cost and Management, 53(3): 17-21.

Mitchell, W. 1991. "Dual clocks: Entry order influences on incumbent and newcomer market share and survival when specialized assets retain their value." Strategic Management Journal, 12: $85-100$.

Mitchell, W. 1994. "The dynamics of evolving markets: The effects of business sales and age on dissolutions and divestitures." Administrative Science Quarterly, 39: 575-602.

Mitchell, W., J.M. Shaver and B. Yeung. 1994. "Foreign entrant survival and foreign market share: Canadian companies' experience in United States medical sector markets." Strategic Management Journal, 15: 555-567.

Moulton, W.N. and H. Thomas. 1993. "Bankruptcy as a deliberate strategy: Theoretical consideration and empirical evidence." Strategic Management Journal, 14: 125-135.

O'Neill, H.M. and J. Duker. 1986. "Survival and failure in small business." Journal of Small Business Management, 24(1): 30-37.

Pennings, J.M., K. Lee and A. Witteloostujin. 1998. "Human capital, social capital, and firm dissolution." Academy of Management Journal, 41: 425-440.

Phillips, B.D. and B.A. Kirchhoff. 1989. "Formation, growth, and survival: Small firm dynamics in the US economy." Small Business Economics, 1(1): 65-74.

Preisendorfer, P. and T. Voss. 1990. "Organizational mortality of small firms: The effects of entrepreneurial age and human capital." Organization Studies, 11(1): 107-129.

Ranger-Moore, J. 1997. "Bigger may be better, but is older wiser? Organizational age and size in the New York life insurance industry." American Sociological Review, 62: 903-920.

Rumelt, R.P. 1984. "Towards a strategic theory of the firm." In R. Lamb (Ed.), Competitive Strategic Management. Englewood Cliffs, NJ: Prentice-Hall.

Rumelt, R.P. 1991. “How much does industry matter?” Strategic Management Journal, 12: 167185.

Singh, J.V., R.J. House and D.J. Tucker. 1986. "Organizational change and organizational mortality." Administrative Science Quarterly, 31: 587-611. 
Singh, J.V., D.J. Tucker and R.J. House. 1986. "Organizational legitimacy and the liability of newness.” Administrative Science Quarterly, 31: 171-193.

Sitkin, S.B. 1992. "Learning through failure: The strategy of small losses." In B.M. Staw and L.L. Cummings (eds.) Research in Organizational Behavior, 14: 231-266, Greenwich, CT: JAI Press.

Sorensen, J.B. and T.E. Stuart. 2000. "Aging, obsolescence and organizational innovation." Administrative Science Quarterly, 45: 81-112.

Stearns, T.M., N.M. Carter, P.D. Reynolds and M. Williams. 1995. "New firm survival: Industry, strategy and location." Journal of Business Venturing, 10: 23-42.

Stinchcombe, A.L. 1965. "Organizations and social structure.” In J.G. March (Ed.), Handbook of Organizations. Chicago: Rand-McNally.

Teece, D.J., G. Pisano and A. Shuen. 1997. "Dynamic capabilities and strategic management." Strategic Management Journal, 18: 509-533.

Thornhill, S. and R. Amit. 1998. "Growth management of emergent firms in Canada." Frontiers of Entrepreneurship Research, P. Reynolds et al. (eds), pp. 381-392. Babson Park, MA: Babson College.

Thornhill, S. and R. Amit. 2000. "Young firm growth: An analysis of strategy and context." In R. Bresser et. al (eds) Winning Strategies in a Deconstructing World. Sussex, UK: John Wiley \& Sons (In Press).

Venkataraman, S., A.H. Van de Ven, J. Buckeye and R. Hudson. 1990. "Starting up in a turbulent environment: a process model of failure among firms with high customer dependence." Journal of Business Venturing, 5: 277-295.

Wernerfelt, B. 1984. "A resource-based view of the firm." Strategic Management Journal, 5: 171-180.

Wichman, H. 1983. “Accounting and marketing - Key small business problems." American Journal of Small Business, 7: 19-26. 